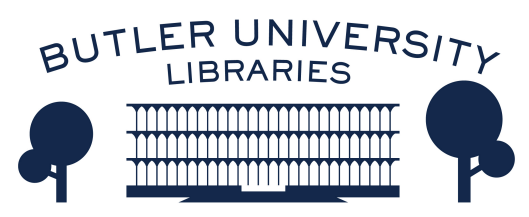

Journal of Hindu-Christian Studies

Volume 13

Article 14

January 2000

\title{
Book Review: "Religious Conversion Movements in South Asia: Continuities and Change, 1800-1900"
}

Ronald Neufeldt

Follow this and additional works at: https://digitalcommons.butler.edu/jhcs

Part of the Religion Commons

\section{Recommended Citation}

Neufeldt, Ronald (2000) "Book Review: "Religious Conversion Movements in South Asia: Continuities and Change, 1800-1900"," Journal of Hindu-Christian Studies: Vol. 13, Article 14.

Available at: https://doi.org/10.7825/2164-6279.1234

The Journal of Hindu-Christian Studies is a publication of the Society for Hindu-Christian Studies. The digital version is made available by Digital Commons @ Butler University. For questions about the Journal or the Society, please contact cbauman@butler.edu. For more information about Digital Commons @ Butler University, please contact digitalscholarship@butler.edu. 


\section{BOOK REVIEWS}

\section{Religious Conversion Movements in South Asia: Continuities and Change, 1800-1900. Geoffrey A. Oddie (Ed.). Surrey: Curzon Press, 1997, 231pp.}

WHILE THE FOCUS in this volume is mainly on conversions to Christianity in India, the authors attempt to explore and raise issues relevant to conversions in general and to apply theories of conversion (particularly those of Rambo and Horton) to the analysis of conversions in India. In his Introduction Oddie raises the question, "What is conversion?" He offers five responses to the question - a change in religious belief, a change in affiliation, an inner transformation, a change of fellowship, a sign of a sense of dissatisfaction with tradition and identity. Conversion, he points out, can result in dual identities, requiring an attempt to find a viable balance between the old and the new. The chapters, it is claimed, address not only the meaning of conversion, but also continuities and change, and the social, economic, and political factors involved in change. Some do this less well than others.

Avril Powell ("Processes of Conversion to Christianity in Nineteenth Century NorthWestern India") in treating cases of conversion among members of the educated elite (Brahman and Ashraf), places the emphasis on conversion as a process and as spiritual re-orientation. The examples produced are those of Nilakantha/Nehemiah Goreh, Ram Chandra/Yesudas, Abd alMasih, and Imad ud-din. Relying on their own conversion accounts, Powell provides an overview of their spiritual journeys, underlining the sense of spiritual crises in these accounts as indicative of conversion as a process.

Oddie's chapter ("Old Wine in New Bottles? Kartabhaja (Vaishnava) Converts to Evangelical Christianity in Bengal, 1800- $\left.1845^{\prime \prime}\right)$ is an attempt to test Horton's intellectualist approach to understanding conversion. While Oddie rejects the wholesale application of Horton's thesis, he does argue that the Kartabhaja's must have seen a connection between their own concepts of the guru, incarnation, and bhakti and the teachings of the missionaries. The evidence for such a connection, however, appears to be a deliberate attempt on the part of the missionaries to make the connection. Whether the Kartabhajas themselves made the connection is not at all clear.

George Oommen's discussion ("The Strength of Tradition and Weakness of Communication: Central Kerala Dalit Conversion") runs in the opposite direction. $\mathrm{He}$ argues that pre-existing Dalit ideas were often obstacles to conversion rather than facilitators in the conversion process. $\mathrm{He}$ also rejects putting too much emphasis on social factors in explaining conversions among the Dalits. While his challenge to Horton's thesis may be correct, Oommen leaves himself open to the challenge of relying almost exclusively on missionary accounts of Pulaya beliefs and the reasons for Pulaya conversions.

Henriette Bugge ("The French Mission and Mass Movements") in her chapter on mass conversions to Catholicism in the Madras Presidency in the late nineteenth century challenges the simplistic view that mass conversions were responses to preaching against caste. She points out that the French Mission not only accepted caste but accommodated itself to existing societal rules and expectations. She argues convincingly that mass conversions must be understood in the context of other 
movements seeking new identities at a time of profound social change.

Moulton ("The Beginnings of the Theosophical Movement in India, 18791885: Conversion and Non-Conversion Experiences") is an exception to the other chapters in this volume in that it deals ostensibly with conversion moving in the other direction, toward Hinduism. It is a sensitive treatment of Hume's spiritual journey to a troubled relationship with Theosophy, to his rejection of Theosophy, and conversion to Advaita. Moulton may, in the end, be too convinced of Hume's eventual view of the Theosophical Society - a selfish organization that turned its back on its philanthropic and societal concerns. Does such a judgement of the Society ignore the overall utopian goals of the Society and its teachings?

Copley ("George Uglow Pope contra Vedanayagam Sastriar: A case study in the clash of 'new' and 'old' mission") provides a wealth of information concerning differences in mission strategies through his juxtaposition of old and new missions in mid-nineteenth-century Tanjore. The old mission emphasized accommodation to existing belief and practice while the new mission expected converts to shake off old loyalties. That Copley finds the latter unrealistic is a given, since his starting point is that conversion is a process of adjustments between the demands of the new faith and old loyalties. The attitude of the old mission is highlighted through the case of Vedanayagam Sastriar, a convert and court poet and the example of the new is the controversial and argumentative George Uglow Pope.
A dominant theme running through the various chapters and case studies is the emphasis on conversion as a process. Indeed the volume offers a good deal of useful and interesting information on this process. Less successful is the attempt to deal with the factors leading to and supporting conversion. A variety of factors are mentioned (pre-existing beliefs, social change, strategies of communication) but none of these are developed in any sustained fashion. Disappointing is the fact that not enough attention is given to the process of self-definition by the converts themselves. The business of dual loyalties is mentioned in the introduction but not taken up in any of the chapters, except in hints here and there. Yet this would appear to be a significant item in the conversions of members of the educated elite, the mass movements, and the controversy between Pope and Sastriar. Crucial in this respect is allowing the converts to have their own voice. This is done successfully in Moulton's account of Hume and in Copley's treatment of conflict between old and new mission, but seems to be missing in the other chapters, even in Powell's treatment of the conversion of members of the educated elite.

Nonetheless, this is a significant addition to the growing tradition of scholarship on religious conversion, and a valuable resource for scholars and students who are interested in religious, social, and cultural developments of South Asia.

Ronald Neufeldt University of Calgary

Monastic Journey to India. M. Basil Pennington. Junction City, OR: Beacon Point Press, 1999, 178 pp.

THE PERSONAL JOURNAL of $M$. Basil Pennington, Trappist monk and popular teacher of the Centring Prayer, followed upon his attendance at the third All-Asian Monastic Conference in Sri Lanka in 1980: Although previously published twenty years ago, the journal is today as fresh and current as it was during his sixweek pilgrimage to Christian, Hindu, and Buddhist centres of asceticism and 